\title{
Can Professional Accountant Carry out their Code of Ethics in Reporting?
}

\author{
Md. Rafiqul Islam \\ Senior Lecturer \\ Department of Business Administration \\ Metropolitan University, Sylhet, Bangladesh \\ E-mail: rafiqul@metrouni.edu.bd \\ Md. Nasir Uddin \\ Lecturer \\ Department of Business Administration \\ North East University Bangladesh, Bangladesh \\ E-mail: nuddin@neub.edu.bd \\ Urmee Ghose \\ Senior Lecturer \\ Department of Business Administration \\ Metropolitan University, Sylhet, Bangladesh \\ E-mail: urmee@metrouni.edu.bd
}

\begin{abstract}
Code of ethics is already established for professional accountant of Bangladesh in public practice and business. Every professional accountant follows this code of ethics to maintain their professionalism as well as reporting. The purpose of this research to investigate some threats those are faced by professional accountant to carry out their code of ethics. This study based on a sample of 61 professional accountants working at different audit firm and different business organization in Bangladesh. Data analyzed by using SPSS 17 and one sample statistics and one sample test was used as analytical tools in this study. There are 18 variables considered from integrity, objectivity, professional competence and due care aspect. It is found that professional accountant face various self-interest threat and selfreview threat in reporting and financial report does not provide accurate information for tax purpose after audited in many cases.
\end{abstract}

Keywords: Professional Accountant, Code of Ethics, Reporting.

\section{Introduction}

Accounting is a financial system which provides adequate information to interested users for their decision making and where professional accountants part a great role to ensure the authenticity of information through auditing or consultancy. (Akenbor \& Tennyson, 2014) states that accounting is responsible for sound financial reporting, effective management of financial resources to help the investors, creditors, employees, business community as well as government to make decisions. Investor and interested parties are loss their confidence when the professional accountant cannot provide actual financial information through financial reporting. Accountant should follow ethical code of conducts in reporting for the betterment of sociological as well as governmental purpose (Fogarty, 1995). A professional accountant should be fair, honest and sincere in their work by following guided rules and regulations (Boston et al., 2011). For exploring superior performance of a professional accountant, IFAC provides code of ethics for them. Accountant should follow professionalism maintaining code of ethics to provide true and fair audit report for corporate decision making (Nigam, 2008). Every professional accountant should obey this code of ethics to maintain professionalism. Sometimes there arise some perceived causes of ethical failure (this study try to examines 
the factors that causes ethical failure or not). (Armstrong et al., 2013) highlighted ethical education is virtue help to learn ethical behavior and give motivation with moral development to professional accountant. Professional accountant not only an accountant but also act as an auditor in various organizations. Every listed company has to conduct a statutory audit in each year according to company act 1994. Besides this every company has to conduct financial audit in every year. In that context, professional accountant are responsible for conduction these audit and they must compile their ethics and professionalism for that purpose. In this study we try to explore the threats to carry code of ethics for professional accountants in financial reporting.

\section{Literature Review}

The practice of accounting is a highly experienced and technical profession that affects public wellbeing. Accountant need to be maintaining professionalism. Simply, professionalism is the proficiency and skill expected of a profession. Professionalism is the traits that characterize or mark a professional person in an occupation or business environment. Professionalism denotes a commitment to carry out professional responsibilities, adhere to ethical principles that benefits the human being (Al-Rubaish, 2010). Professional accountant is a person who has the requisite skill and experience in establishing and maintaining accurate financial records for an individual or a business. (Marriott \& Marriott, 2000) stated professional accountant needs to experienced in such a way that increase the financial skills of their clients. A professional accountant may be a salaries employee, partner, director, an owner manager, a volunteer working for one or more employing organizations. Accountant needs to be highly skill in issuing professional opinions. A professionally qualified account can carry on their responsibility accurately and transparently to provide quality information which is demanded by the users of these information. Accountant should maintain their professional activities in reporting with accordance of Financial Reporting Act (FRA). FRA guide professional accountant to provide accurate financial report by covering issues such as audit independence, corporate governance, internal control assessment, and enhanced financial disclosure (Hossen, 2016). Financial reporting follow the conceptual framework which is based some standards rules and regulations and these rules and regulation should be followed by the professional accountant in their reporting. Managerial and financial decision of a company depends on reliability of accounting information provided by professional accountant (Yasemin Zengin Karalbrahlmoglu \& Var, 2009). A professional accountant's responsibility is not only to satisfy needs of an individual client or employer, but need to fulfill responsibility exclusively in public interest by following recommended code of ethics. Code of ethics for corporate codes of ethics is constructed by which companies can be ethically audited for compliance (Schwartz, 2002). Code of ethics is a set of standards or rules that consist of integrity, objectivity, professional competence and due care, confidentiality and professional behavior. Organizational cultures and environment helps accountants to provide good financial report by maintaining code of ethics (Mathenge, 2012). Five aspects of ethical principles try to reflect the main values shared by interest groups to whom professional accountant serve (Espinosa-Pike \& Barrainkua-Aroztegi, 2014). A professional accountant should compliance with required code of ethics. Professional accountant should not allow bias, conflict of interest or undue influence of others. Ethical failure leads to misleading and biased information in reporting. Code of ethics guides professional accountant to harmonization of accounting practices by following accounting rules and regulations (Graffikin \& Lindawati, 2012). Ethical failure is a bad decision that intentionally or unintentionally breaks a law or violates principles of code of ethics or conducts. Ethical failure caused by lack of operational principles or willingness to abandon principles in the face of competitive pressure (Ludwig \& Longenecker, 1993). Investors need true and fair audit report of an organization which helps them to make investing decision. (Horomnea \& Pasco, 2012) Professional accountant need to conduct code of ethics properly to quantify the financial position and performance of a company. Ethical orientation very much needed for professional accountant to provide quality service in reporting by following code of ethics (Esmand-Kiger \& Connie, 2004). Investors, creditors, employees and other business community as well as governments and the public may rely on the activities of professional accountants in business. An accountant needs professional knowledge and skills to provide real values of accounts in reporting (Falt, 1995). Professional accountant may accountable for providing effective financial management and competent guidance on a variety of business-related matters. Professional accountant should have the competencies such as business knowledge, interpersonal skills, IT skills, personal qualities, information provider, decision supporter to provide true and fair view audit report (II \& Crittenden, 2014). Professional accountant tangible behavior in reporting depends on some issues such as independence, facing threats, conflict of interests, code of ethics, adequate evidence, tax information, adequate transaction data, updated financial statement, internal control system etc. If these issues are misleading, professional account can't provide true and fair audit report. (Reiter, 1997) suggested accountant should adopt modern rules and regulation in reporting with the ethics of care. Without the proper examination of these issues, the professional accountant will not able to provide true and accurate financial statement in reporting. Financial report is a formal record where relevant financial information is presented in a structured manner and in a form easy to understand. Investor's decision depends on the true and accurate 
financial report because financial report shows the actual state of affairs of the company (Yadav, 2013). Professional accountant faces these issues as obstacle in presentation of audit report and financial statement. They need to work independently to provide unbiased and accurate audit report. In this study, we try to find out the critical factors those are related with professional accountant code of ethics in reporting. Professional accountant must follow audit standards and IASB standard in their reporting accordance with the code of ethics or conduct.

\section{Theoretical Framework}

The codes of ethics of professional accountant to make financial reporting are already established. According to ICAB and IFAC, professional accountant needs to follow all of the principles of code of ethics: integrity, objectivity, professional competence and due care, confidentiality and professional behavior. In our study, we analyzed the professional accountant duties and responsibilities in financial reporting accordance with code of ethics.

Integrity imposes an obligation on all accountants to be honest in professional relationships and also implies fair dealings and truthfulness. It provides actual audit report and verified adequate evidence against every transaction.

Objectivity imposes an obligation on all professional accountants to Conduct independent examination to provide unbiased audit report and provide audit report from free of conflicts.

Professional competence and due care implies professional accountant should maintain professional knowledge and skill to conduct audit with adequate evidence, build up an effective internal control system and provide updated audit report accordance with professional standards.

Confidentiality implies accountant should publish adequate information on financial statement for investor decision making, provides accurate information for tax purpose and perform independently to disclose financial matters.

Professional behavior imposes auditor need to maintain all IFAC \& ICAB code of ethics, prepare audit report according to Bangladesh Audit Standard (BAS) and ensure all qualitative characteristics according to IASB framework.

\section{Objectives of the Research}

The study has been conducted for following purposes:

- It aims to know the performance of professional accountant according to code of ethics.

- To find out the perceived causes which may affect to perform as professional accountant.

- To identify the primitive actions those may enhance the performance of professional accountant and can reduce ethical failure event.

\section{Methodology of the Research}

\subsection{Questionnaire Design}

To achieve the objective of the study, A survey questionnaire has been used. The questionnaire developed by Likert Scale for measuring the performance of professional accountant. This questionnaire divided into two parts. Part $-\mathrm{A}$ included the demographic information and Part-B included respondents opinion about their performance.

\subsection{Data Collection}

The Study is compiled with the primary data. Respondents are the member of ICAB who are recognized as professional accountant. The survey conducted during the period from April 2018 to July 2018. There are 61 professional accountants had responded to the survey, 9 respondents are not participated on the survey with a response rate of $87.14 \%$.

\section{Data Analysis}

This study is descriptive research. Data analyzed by employing several statistical technique and factor analysis. A well-known Statistical package SPSS (Statistical Package for Social Science) 17 version was used for primary data analyzing. This study used principle component factor analysis which indicates the core code of ethics and it extracted with six variables. All variables were rated on 5 -point likert scale ( $1=$ Strongly Disagree to $5=$ Strongly Agree.

Table-1: One - Sample Statistics

\begin{tabular}{|c|c|c|c|c|}
\hline & $\mathbf{N}$ & Mean & Std. Deviation & Std. Error Mean \\
\hline $\begin{array}{l}\text { Faced various threats to deliver actual } \\
\text { audit report }\end{array}$ & 61 & 4.19672 & .792037 & .101410 \\
\hline $\begin{array}{l}\text { Audit activities are relaxed when } \\
\text { audit fee is not satisfactory }\end{array}$ & 61 & 2.91803 & 1.129824 & .144659 \\
\hline $\begin{array}{l}\text { Verifying adequate evidence against } \\
\text { every transaction }\end{array}$ & 61 & 2.77049 & 1.346519 & .172404 \\
\hline Conduct independent examination to & 61 & 3.93443 & 1.030677 & .131965 \\
\hline
\end{tabular}




\begin{tabular}{|c|c|c|c|c|}
\hline provide unbiased audit report & & & & \\
\hline $\begin{array}{l}\text { Able to provide audit report from free } \\
\text { of conflicts }\end{array}$ & 61 & 3.62295 & 1.035438 & .132574 \\
\hline $\begin{array}{l}\text { Self-review threat (There are practice } \\
\text { that firm prepare financial statement } \\
\text { and then audits review them) }\end{array}$ & 61 & 3.34426 & 1.209480 & .154858 \\
\hline $\begin{array}{l}\text { Maximum sample size has been taken } \\
\text { when conducting audit }\end{array}$ & 61 & 3.47541 & 1.074035 & .137516 \\
\hline $\begin{array}{l}\text { Auditor plays an important role to } \\
\text { build up an effective internal control } \\
\text { system }\end{array}$ & 61 & 3.88525 & 1.096941 & .140449 \\
\hline $\begin{array}{l}\text { Financial statement is updated \& } \\
\text { prepared in accordance with } \\
\text { applicable technical and professional } \\
\text { standards }\end{array}$ & 61 & 4.22951 & .642740 & .082294 \\
\hline $\begin{array}{l}\text { Adequate information published on } \\
\text { F/S which needs for investor decision } \\
\text { making }\end{array}$ & 61 & 4.08197 & .585807 & .075005 \\
\hline $\begin{array}{l}\text { Financial report provides accurate } \\
\text { information for tax purpose }\end{array}$ & 61 & 3.22951 & 1.039125 & .133046 \\
\hline $\begin{array}{l}\text { Professional accountant must not } \\
\text { disclose information acquired during } \\
\text { the course of his engagement }\end{array}$ & 61 & 4.29508 & .863023 & .110499 \\
\hline $\begin{array}{l}\text { Perform independently to disclose } \\
\text { financial matters }\end{array}$ & 61 & 3.40984 & 1.085926 & .139039 \\
\hline $\begin{array}{l}\text { Auditor maintains all IFAC \& ICAB } \\
\text { code of ethics }\end{array}$ & 61 & 3.73770 & 1.063040 & .136108 \\
\hline $\begin{array}{l}\text { All audit report are prepared } \\
\text { according to Bangladesh Audit } \\
\text { Standard (BAS) }\end{array}$ & 61 & 4.29508 & .919135 & .117683 \\
\hline $\begin{array}{l}\text { Always maintain IAS/IFRS to } \\
\text { prepare F/S in everywhere }\end{array}$ & 61 & 3.49180 & 1.444795 & 184987 \\
\hline 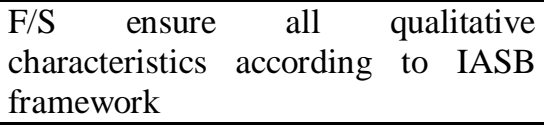 & 61 & 3.75410 & 1.027225 & .131523 \\
\hline $\begin{array}{l}\text { Verifying that transactions are made } \\
\text { in accordance with internal control } \\
\text { system }\end{array}$ & 61 & 3.77049 & .739221 & .094648 \\
\hline
\end{tabular}

In our study we take the hypothesized test value as 3 . Our decision is compared with the score result from all area by response of professional accountant as number 3. From the response of professional accountant, we draw a conclusion about what factors are influences to maintain code of ethics for a professional accountant to carry on their professionalism in reporting. We run sample T-test to draw a conclusion for every dimensions. The null and alternative assumptions are:

Null Assumption A o : $\mu \geq 3$

Alternative Assumption A a: $\mu<3$ 
Table-2: One - Sample Test

\begin{tabular}{|c|c|c|c|c|c|c|c|}
\hline & \multicolumn{6}{|c|}{ Test Value $=3$} & \multirow{3}{*}{$\begin{array}{c}\text { Decision } \\
\text { (Null } \\
\text { Hypothesis) }\end{array}$} \\
\hline & $\bar{t}$ & $\overline{\text { Df }}$ & \multirow[t]{2}{*}{$\begin{array}{l}\text { Sig. (2- } \\
\text { tailed) }\end{array}$} & \multirow[t]{2}{*}{$\begin{array}{c}\text { Mean } \\
\text { Difference }\end{array}$} & \multicolumn{2}{|c|}{$\begin{array}{l}\text { 95\% Confidence } \\
\text { Interval of the } \\
\text { Difference } \\
\end{array}$} & \\
\hline & & & & & Lower & Upper & \\
\hline $\begin{array}{l}\text { Faced various threats to } \\
\text { deliver actual audit } \\
\text { report }\end{array}$ & 11.801 & 60 & .000 & 1.196721 & .99387 & 1.39957 & Reject \\
\hline $\begin{array}{l}\text { Audit activities are } \\
\text { relaxed when audit fee is } \\
\text { not satisfactory }\end{array}$ & -.567 & 60 & .573 & -.081967 & -.37133 & .20739 & Accept \\
\hline $\begin{array}{l}\text { Verifying adequate } \\
\text { evidence against every } \\
\text { transaction }\end{array}$ & -1.331 & 60 & .188 & -.229508 & -.57437 & .11535 & Accept \\
\hline $\begin{array}{l}\text { Conduct independent } \\
\text { examination to provide } \\
\text { unbiased audit report }\end{array}$ & 7.081 & 60 & .000 & .934426 & .67046 & 1.19839 & Reject \\
\hline $\begin{array}{l}\text { Able to provide audit } \\
\text { report from free of } \\
\text { conflicts }\end{array}$ & 4.699 & 60 & .000 & .622951 & .35776 & .88814 & Reject \\
\hline $\begin{array}{l}\text { Self review threat (There } \\
\text { are practice that firm } \\
\text { prepare financial } \\
\text { statement and then audits } \\
\text { review them) }\end{array}$ & 2.223 & 60 & .030 & .344262 & .03450 & .65402 & Reject \\
\hline $\begin{array}{l}\text { Maximum sample size } \\
\text { has been taken when } \\
\text { conducting audit }\end{array}$ & 3.457 & 60 & .001 & .475410 & .20034 & .75048 & Reject \\
\hline $\begin{array}{l}\text { Auditor plays an } \\
\text { important role to build } \\
\text { up an effective internal } \\
\text { control system }\end{array}$ & 6.303 & 60 & .000 & .885246 & .60431 & 1.16619 & Reject \\
\hline $\begin{array}{l}\text { Financial statement is } \\
\text { updated \& prepared in } \\
\text { accordance with } \\
\text { applicable technical and } \\
\text { professional standards }\end{array}$ & 14.940 & 60 & .000 & 1.229508 & 1.06489 & 1.39412 & Reject \\
\hline $\begin{array}{l}\text { Adequate information } \\
\text { published on } \mathrm{F} / \mathrm{S} \text { which } \\
\text { needs for investor } \\
\text { decision making }\end{array}$ & 14.425 & 60 & .000 & 1.081967 & .93194 & 1.23200 & Reject \\
\hline $\begin{array}{l}\text { Financial report provides } \\
\text { accurate information for } \\
\text { tax purpose }\end{array}$ & 1.725 & 60 & .090 & .229508 & -.03662 & .49564 & Accept \\
\hline $\begin{array}{l}\text { Professional accountant } \\
\text { must not disclose } \\
\text { information acquired } \\
\text { during the course of his } \\
\text { engagement }\end{array}$ & 11.720 & 60 & .000 & 1.295082 & 1.07405 & 1.51611 & Reject \\
\hline $\begin{array}{l}\text { Perform independently } \\
\text { to disclose financial } \\
\text { matters }\end{array}$ & 2.948 & 60 & .005 & .409836 & .13172 & .68795 & Reject \\
\hline
\end{tabular}




$\begin{aligned} & \text { Auditor maintains all } 5.420 \\ & \text { IFAC \& ICAB code of } \\ & \text { ethics }\end{aligned}$
$\begin{aligned} & \text { All audit report are } \\ & \text { prepared according to }\end{aligned}$
$\begin{aligned} & \text { Bangladesh Audit } \\ & \text { Standard (BAS) }\end{aligned}$

\section{Discussion}

The current study aims at finding the limitation to perform as professional accountant for reporting according to code of ethics. From our research we can say, professional accountant faced various self-interest and self-review threats for their fair reporting those are make difficulty to carry on their code of ethics in reporting. According to data analysis, professional accountant consent to say, financial reporting does not provides accurate information for tax purpose after conducting audit in many cases and it is also the limitation for professional accountant in reporting.

\section{Scope for Future Research}

In our study, who are the members of Institution of Chartered Accountant of Bangladesh (ICAB) take as respondent? In according to Financial Reporting Act 2015, member of ICAB and ICMAB both are considered as professional accountant at now. So members of Institution of Cost Management Accountants of Bangladesh (ICMAB) are also be a respondents for future researchers.

\section{Conclusion}

Our research able to address such factor may exist in reporting those responsible to unethical practice by a professional accountant. Self-interest and self-review threat mainly exist in providing true and fair reporting and also it was found that financial statements do not provide accurate information for tax purpose after verified by professional accountant. There are not enough research in this field in Bangladesh, respondents are not adequate, and respondents might uncomfortable to say actual fact because it was a self-judgment questionnaire, these limitation arisen to continue our research. Finally we can say these outcomes will be help to professional, institution and related parties to find out the solution.

References

Akenbor, C. O., \& Tennyson, O. (2014). Ethics of Accounting Profession in Nigeria. Journal of Business and Economics , 5 (8), 1374-1382.

Al-Rubaish, A. M. (2010). Professionalism today. Journal of Family and Community Medecine , 17 (1), 1-2.

Armstrong, M. B., Ketz, J. E., \& Owsen, D. (2013). Ethics education in accounting: moving toward ethical motivation and ethical behavior. Journal of Accounting Research, 21 (1), 1-16.

Boston, I., Costuleanu, C., Horomnea, E., \& Costuleanu, M. (2011). Morality, Ethics and True Image in Business Accounting. Journal of Theoritical and Applied Economics , XVIII (2011) (6 (559)), 47-54.

Esmand-Kiger, \& Connie. (2004). Making ethics a pervasive component of accounting education. Management Accounting Quaterly, 5 (4), 42-52.

Espinosa-Pike, M., \& Barrainkua-Aroztegi, I. (2014). A Universal Code Of Ethics For Professional Accountants: Religious Restrictions. Procedia-Social and Behavioral Sciences. , 143, 1126-1132.

Falt, J. P. (1995). Ethics and the accountant. Journal of Business Ethics , 14 (12), 997-1004.

Fogarty, T. J. (1995). Accountant Ethics: A brief examination of neglected sociological dimensions. Journal of Business Ethics , 14 (2), 103-115.

Graffikin, M., \& Lindawati, A. (2012). The Moral Reasoning of Public Accountants in the Development of a Code of Ethics: The Case of Indonesia. Australiasian Accounting, Business and Finance Journal , 6 (1), 3-28.

Horomnea, E., \& Pasco, A.-M. (2012). Ethical and Morality in Accounting Epistemological Approach. Journal of Eastern Eurupe Research in Business and Economics , 2012, 11. 
Hossen, M. S. (2016). Financial Reporting Act (FRA), 2015: A Revolutionary Era for Ensuring Effective Capital Market and Economic Development in Bangladesh. Global Journal of Management and Business Research (D) , $16(1), 13-20$.

II, C. A., \& Crittenden, W. F. (2014). The Accounting Profession's Role in Corporate Governancein Frontier Markets: A Research Agenda. Organizations and Markets in Emerging Economies , 5 (2 (10)).

Ludwig, D. C., \& Longenecker, C. O. (1993). The Bathsheba Syndrom: The ethical failure of successful leader. Journal of Business Ethics , 12 (4), 265-273.

Marriott, N., \& Marriott, P. (2000). Professional accontants and the devdelopment of a management accounting service for the small firm: barriers and possibilities. Management Accounting Research, 11 (4), 475-492.

Mathenge, G. D. (2012). Ethical Dimeiticnsions in Responsible Professionalism and Accounting Procedure in Kenya: A Critical Analysis of Theory and Practice. Research Journal of Finance and Accounting , 3 (2).

Nigam, R. (2008). The Relationship Between Professional Ethics and corporate Profitability. International Journal of Business Studies , 13 (1), 217-229.

Reiter, S. (1997). The ethics of care and new paradigms for accounting practice. Accounting, Auditing and Accountability Journal , 10 (3), 299-324.

Schwartz, M. S. (2002). A Code of Ethics for CorporateCode of Ethics. Journal of Business Ethics , 41 (1-2), 2743.

Yadav, B. (2013). Creative Accounting: A Literature Review. The SIJ Transations on Indistrial, Financial \& Business Management (IFBM) , 1 (5), 181-193.

Yasemin Zengin Karalbrahlmoglu, E. E., \& Var, T. (2009). Ethical Behavior in Accounting: Some Evidence from Turkey. African Journal of Business Management , 3 (10), 540-547.

\section{Copyrights}

Copyright for this article is retained by the author(s), with first publication rights granted to the journal.

This is an open-access article distributed under the terms and conditions of the Creative Commons Attribution license (http://creativecommons.org/licenses/by/4.0/) 